\title{
Microbial loop carbon cycling in ocean environments studied using a simple steady-state model
}

\author{
Thomas R. Anderson ${ }^{1, *}$, Hugh W. Ducklow ${ }^{2}$ \\ ${ }^{1}$ Southampton Oceanography Centre, Waterfront Campus, European Way, Southampton SO14 3ZH, United Kingdom \\ ${ }^{2}$ College of William and Mary School of Marine Science, Rte 1208, Box 1346, Gloucester Point, Virginia 23062, USA
}

\begin{abstract}
A simple steady-state model is used to examine the microbial loop as a pathway for organic $\mathrm{C}$ in marine systems, constrained by observed estimates of bacterial to primary production ratio (BP:PP) and bacterial growth efficiency (BGE). Carbon sources (primary production including extracellular release of dissolved organic carbon, DOC), cycling via zooplankton grazing and viral lysis, and sinks (bacterial and zooplankton respiration) are represented. Model solutions indicate that, at least under near steady-state conditions, recent estimates of BP:PP of about 0.1 to 0.15 are consistent with reasonable scenarios of C cycling (low BGE and phytoplankton extracellular release) at open ocean sites such as the Sargasso Sea and subarctic North Pacific. The finding that bacteria are a major $(50 \%)$ sink for primary production is shown to be consistent with the best estimates of BGE and dissolved organic matter (DOM) production by zooplankton and phytoplankton. Zooplankton-related processes are predicted to provide the greatest supply of DOC for bacterial consumption. The bacterial contribution to $\mathrm{C}$ flow in the microbial loop, via bacterivory and viral lysis, is generally low, as a consequence of low BGE. Both BP and BGE are hard to quantify accurately. By indicating acceptable combinations of parameter values for given BP:PP, the model provides a simple tool for examining the reliability of BP and BGE estimates.
\end{abstract}

KEY WORDS: Microbial loop - Bacterial production · BGE $\cdot$ Models $\cdot$ DOC $\cdot$ Extracellular release Resale or republication not permitted without written consent of the publisher

\section{INTRODUCTION}

A fraction of carbon (C) fixed by phytoplankton in the euphotic zone of marine systems is released as dissolved organic matter (DOM) and recycled via the 'microbial loop' of bacteria, viruses and protozoan grazers (Azam et al. 1994a). This fraction is most exactly quantified by comparing the ratio of bacterial respiration to primary production (Jahnke \& Craven 1995), although in practice respiration measurements of this kind are rarely made (Williams 2000). The ratio of bacterial carbon demand (BCD) to net particulate primary production (PP) is instead often used as a mea-

*E-mail: tra@soc.soton.ac.uk sure of the magnitude of this pathway as a sink for organic C (Cho \& Azam 1988). BCD is bacterial production (BP) divided by bacterial growth efficiency (BGE). A synthesis of published studies by Cole et al. (1988) indicates that BP in the euphotic zone is typically 20 to $30 \%$ of PP, although recent reviews (Ducklow 1999, 2000) suggest that BP:PP in open ocean systems is usually somewhat lower. The measurement of BGE in natural systems is difficult, however, and so observations of BP are often utilized in concert with assumed values of BGE when estimating BCD. BGE assigned in this manner typically range between 0.4 and 0.5 (e.g. Kirchman et al. 1993, Conan et al. 1999, Møller \& Nielsen 2000). In a typical example, combining a BP:PP of 0.20 and a BGE of 0.45 gives rise to the apparently reasonable BCD:PP of 0.20/0.45 $=0.44$. 


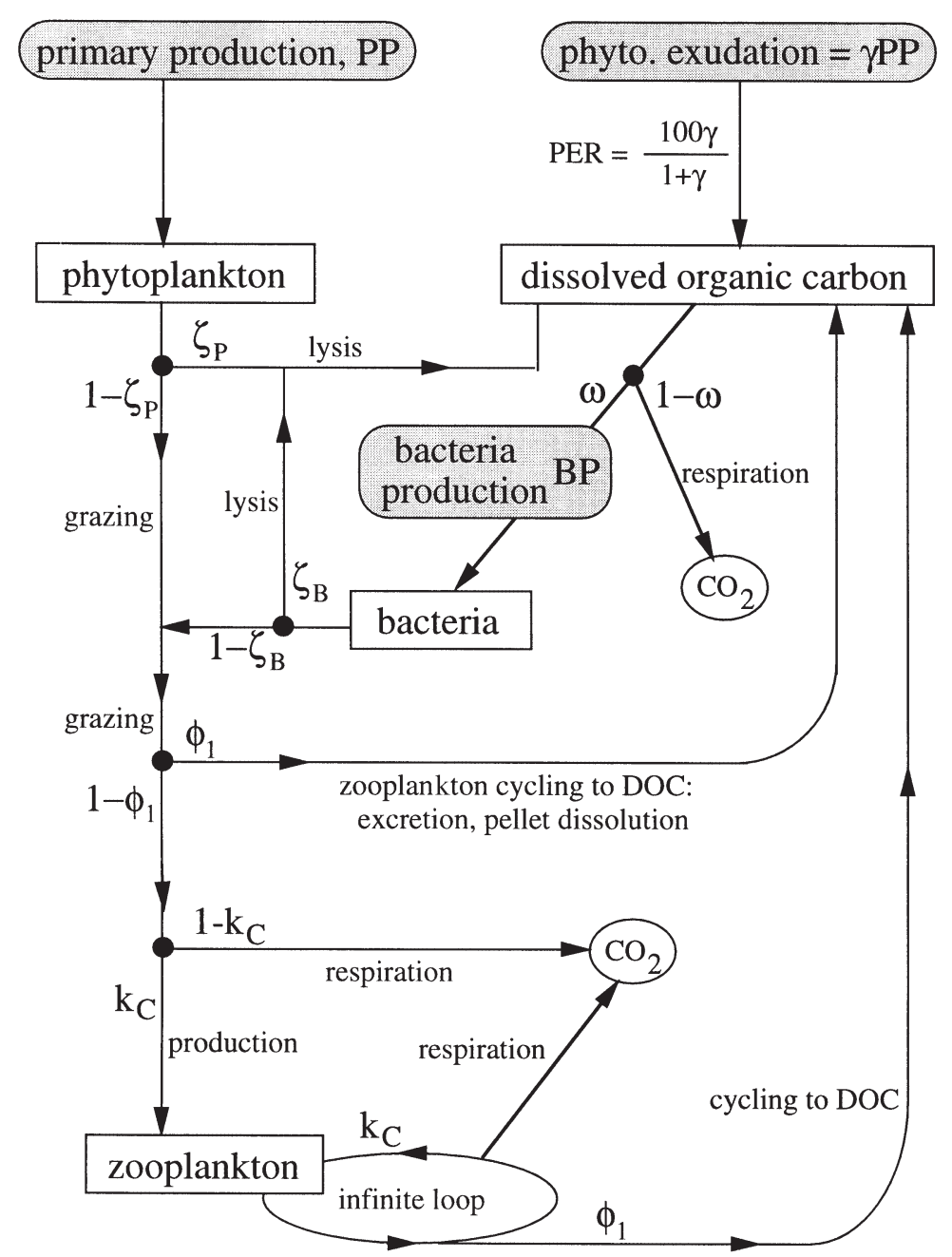

Fig. 1. Flow diagram of the model, illustrating sources, sinks and cycling processes. Parameterization of various flows is indicated. See text for explanation and equations

However a recent literature review of BGE in open ocean areas by del Giorgio \& Cole (2000) indicates a mean value of 0.15 . Replacing the BGE of 0.45 with a $\mathrm{BGE}$ of 0.15 in the above calculation gives a BCD:PP of 1.33, which at face value would suggest that in excess of $100 \%$ of PP passes through the microbial loop.

A number of factors should be taken into consideration when analyzing $\mathrm{C}$ flows in this way. Firstly, BP, and hence also $\mathrm{BCD}$, are not constrained by $\mathrm{PP}$, because each $\mathrm{C}$ atom can be cycled any number of times around the microbial loop before being respired. Indeed it is possible to construct food-web scenarios in which BP exceeds the input of organic $\mathrm{C}$ if growth efficiencies of bacteria and zooplankton are sufficiently high (Strayer 1988). In contrast bacterial respiration (BR), in conjunction with zooplankton respiration (ZR), cannot exceed the supply of organic C. Secondly, alternate sources of organic $C$ should be considered. Most routine ${ }^{14} \mathrm{C}$-primary production measurements do not include estimates of the extracellular production of organic carbon (EOC) by exudation or leakage (Bjørnsen 1988), which is an additional source of $\mathrm{C}$ for bacteria. There is little consensus on the magnitude and factors controlling EOC in aquatic systems. Expressed as a percentage of extracellular release (PER), this source of DOC typically accounts for about $10 \%$ of total primary production (particulate plus EOC) in natural environments (Nagata 2000). Allochthonous DOC may also contribute a significant fraction of the BP in coastal waters. Pédros-Alió et al. (1999) observed an increase in BP:PP from 0.09 at an open sea station to 0.83 at a coastal station in the northwestern Mediterranean Sea. In estuaries, BP is often not correlated with PP because exogenous DOM inputs confound the relationship (Shiah \& Ducklow 1997). Finally, BP and PP may be decoupled in time and space such that they are difficult to compare on the same scales at which measurements are made. For example high BP may in some instances be a consequence of the consumption of organic material that had accumulated during the preceding productive months (e.g. Azam et al. 1994b, Børsheim 2000).

Here we use a simple steady-state model to examine the microbial loop as a pathway for $\mathrm{C}$ using a fully defined description of the system which embraces both cycling processes and the sources and sinks of organic matter. Model solutions are explored for 3 contrasting marine systems - the Sargasso Sea, equatorial Pacific (EqPac) and subarctic North Pacific (SubNPac). Measured estimates of BP:PP for each location are used to determine fluxes thoughout the microbial system, and thereby gain insight into the magnitudes of various sources and sinks of organic C. Results are used to help constrain acceptable ranges of model parameters, which are often not particularly well known because of methodological difficulties in obtaining accurate estimates.

\section{MODEL DESCRIPTION}

A flow diagram of the food web model used to describe $\mathrm{C}$ cycling through the microbial loop is shown in Fig. 1. The model is a steady-state flow analysis, embracing 4 main processes: production of organic $\mathrm{C}$ by phytoplankton, cycling of particulate organic mat- 
Table 1. Model parameters (recommended values indicated) and variables. EOC: extracellular production of organic carbon; PER: percentage of extracellular release

\begin{tabular}{|c|c|c|}
\hline \multicolumn{3}{|c|}{ Parameters } \\
\hline$\omega$ & Bacteria C gross growth efficiency & $0.15^{\mathrm{a}}$ \\
\hline$\phi_{1}$ & $\begin{array}{l}\text { Fraction grazed material cycled to DOC } \\
\text { during a single event }\end{array}$ & 0.3 \\
\hline$k_{\mathrm{C}}$ & Zooplankton C net production efficiency & 0.36 \\
\hline$\gamma$ & Production of EOC, normalised to PP & $0.111^{\mathrm{b}}$ \\
\hline$\zeta_{\mathrm{B}}$ & Viral lysis as fraction of bacteria mortality & 0.25 \\
\hline$\zeta_{\mathrm{P}}$ & $\begin{array}{l}\text { Phytoplankton lysis as fraction of } \\
\text { phytoplankton mortality }\end{array}$ & 0.05 \\
\hline \multicolumn{3}{|c|}{ Variables } \\
\hline PP & Particulate primary production & \\
\hline BP & Bacterial production & \\
\hline $\mathrm{ZP}$ & Zooplankton production & \\
\hline $\mathrm{BR}$ & Bacterial respiration & \\
\hline ZR & Zooplankton respiration & \\
\hline
\end{tabular}

ter (POM) to DOC via grazers, cyling via viral lysis, and bacterial consumption. The flows, but not stocks, of POM and DOM are quantified by the model. Model parameters and variables are listed in Table 1.

Carbon sources are PP and phytoplankton release of EOC. Ecologists generally believe that the ${ }^{14} \mathrm{C}$ method for measuring primary production provides estimates that are close to net production (e.g. Eppley \& Sloan 1965), although it may sometimes measure something nearer gross (e.g. Langdon et al. 1995). We define PP as net particulate primary production. EOC release is quantified by normalizing it to PP using the parameter $\gamma$, where EOC release $=\gamma \mathrm{PP} ; \mathrm{PER}=100 \gamma /(1+\gamma)$. The sum of the 2 production terms, $\mathrm{PP}(1+\gamma)$, is balanced by $\mathrm{ZR}$ and $\mathrm{BR}$ at steady state. Bacterial consumption of DOM equals the flux to the DOC pool at steady state. A fraction of this consumption, equal to the BGE, is utilized by bacteria for growth, with the remainder respired as $\mathrm{CO}_{2}$. Model solutions are derived using measured estimates of BGE for each ocean location.

The most complicated aspect of the flow analysis is the description of $\mathrm{C}$ transfer via phytoplankton, bacteria and zooplankton loss terms to the DOC pool, ready for consumption by bacteria. Two types of loss term are considered: grazing by zooplankton and viral lysis. Model zooplankton are taken to represent the entire grazer community including protozoans and metazoans. Compartmentalization of grazers into a single unit is a common feature of many ecosystem models (e.g. Fasham et al. 1990, Anderson \& Williams 1998). In effect this assumes that processes recycling POM to DOC are the same in different grazers. As a first approximation we believe this to be a reasonable assumption, bearing in mind the difficulty in quantifying the processes involved. Our strategy is to minimize the complexity of the model as much as possible. Zooplankton grazing dominates POM losses in oceanic systems where primary and secondary production are tightly coupled (Banse 1992, Landry et al. 1997, Rivkin et al. 1999). The fraction of grazed material which passes to DOC during a single foraging event, parameter $\phi_{1}$, is the sum of various modes of grazer-associated DOC release: so-called 'sloppy feeding' (release of dissolved compounds when prey cells are broken by the mouthparts of crustacean zooplankton), excretion, and egestion and dissolution of fecal material (Strom et al. 1997). Sloppy feeding losses are negligible if prey can be ingested whole; so this production pathway is probably of minor significance in phagocytic microzooplankton as well as some larger grazers. Lampert (1978) found that freshwater cladocera release 4 to $17 \%$ of ingested prey C as DOC during the initial stage of feeding. Grazing is often dominated by microzooplankton, except in areas characterized by large algal blooms (Dam et al. 1993, Verity et al. 1993, Landry et al. 1997); so sloppy feeding is probably a negligible loss term in the ocean systems of interest here. Direct excretory losses to DOC are probably small (Nagata 2000), e.g. 3 to $9 \%$ of intake (Taylor et al. 1985). The final mode of zooplankton DOC release, from fecal pellets, has been proposed as an important source (Jumars et al. 1989, Lampitt et al. 1990, Nagata 2000), with as much as $50 \%$ of $\mathrm{C}$ in pellets being rapidly solubilized (Urban-Rich 1999). Particle-attached bacteria exhibit high hydrolytic activities but are inefficient at utilizing the resulting products, which can lead to large-scale release of organic matter from sinking particles to the dissolved phase (Smith et al. 1992, Unanue et al. 1998). In common with other models (e.g. Anderson \& Williams 1998), we therefore assume that all fecal material is converted to DOC before being remineralized by bacteria. Between 10 and $40 \%$ of ingested prey could then contribute to DOC via pellets, based on an assimilation efficiency (AE) between 0.6 and 0.9 (e.g. Verity 1985, Hassett \& Landry 1988, Anderson 1994). Parameter $\phi_{1}$ is the sum of these grazer-associated DOM fluxes. If sloppy feeding losses are considered negligible, $5 \%$ of ingested $\mathrm{C}$ is directly excreted and $25 \%$ egested as pellets (AE $75 \%$ ), then the overall loss is $30 \%\left(\phi_{1}=0.3\right)$. This parameter value is similar to other published estimates of DOC release via grazers. After surveying the literature, Nagata (2000) suggested that protozoan and metazoan grazers release $20-30 \%$ and $10-20 \%$ of ingested prey organic $\mathrm{C}$ as DOC respectively, with egestion of unassimilated prey being a major pathway. Strom et al. (1997) found that between 16 and $37 \%$ of algal $\mathrm{C}$ was released 
during herbivorous grazing by heterotrophic protists, although their estimate depended on the value assigned to BGE.

Zooplankton are themselves subsequently grazed by higher predators, which in the model are ordered in an infinite chain, with fraction $\phi_{1}$ passing to DOC at each trophic level. The fraction of any one unit of phytoplankton or bacteria C that is cycled to DOC as it passes through the chain of grazers, $\phi_{\infty}$ is:

$$
\phi_{\infty}=\phi_{1} \sum_{i=0}^{\infty}\left[\left(1-\phi_{1}\right) k_{\mathrm{C}}\right]^{i}=\frac{\phi_{1}}{1-\left(1-\phi_{1}\right) k_{\mathrm{C}}}
$$

where $k_{\mathrm{C}}$ is zooplankton net production efficiency (fraction of assimilated $\mathrm{C}$ allocated to new biomass, remainder respired). Published estimates of $k_{\mathrm{C}}$ vary from less than 0.1 to around 0.6 depending on food concentration, body size and temperature (e.g. Vidal 1980, Le Borgne 1982). Straile (1997), based on a comprehensive literature search, demonstrated that gross growth efficiency (GGE; fraction of total intake allocated to new biomass) of planktonic crustaceans is typically 0.2 to 0.3 , in which case $k_{\mathrm{C}}$ should be at least as great. We show model results for $k_{\mathrm{C}}$ between 0.29 and 0.43 (standard value 0.36), based on GGE $=0.2-0.3$, $\phi_{1}=0.3$, and $k_{\mathrm{C}}=\mathrm{GGE} /\left(1-\phi_{1}\right)$.

Viral lysis of bacteria and phytoplankton is the second route in the model via which particulate material is cycled to DOC. The magnitude of lysis relative to zooplankton grazing as a source of DOC is not well known in the open ocean. The most likely fate of material lysed by viruses is immediate or eventual availability to bacteria (Fuhrman 2000). Gobler et al. (1997) estimated that $37 \%$ of the total $\mathrm{C}$ of algal cells lysed by viruses is released as DOC, much of which is rapidly consumed by bacteria. Much of the remaining $63 \%-$ particulate cell debris - could also contribute to DOC given time for decomposer organisms to act on it. We therefore assume that the products of viral lysis contribute directly to DOC, with no associated flux to $\mathrm{CO}_{2}$ as in the grazer pathway. Viral lysis is parameterized as fixed fractions of bacteria and phytoplankton mortality, $\zeta_{\mathrm{B}}$ and $\zeta_{\mathrm{P}}$ (with remaining losses attributable to grazing). It is generally thought that viruses are responsible for 10 to $50 \%$ of bacterial mortality in surface waters (Fuhrman 1999); we use a default value for $\zeta_{\mathrm{B}}$ of 0.25 . The impact of viruses on oceanic phytoplankton mortality is not well known, but generally thought to be less than that on bacteria (Fuhrman 1999, Wilhelm \& Suttle 1999). When undertaking simple flow analyses of C flows in marine systems, Fuhrman (1999) and Nagata (2000) assumed that 7 and $3 \%$ respectively of phytoplankton mortality was due to viruses. A default parameter setting of $\zeta_{\mathrm{P}}=0.05$ is used here, although model sensitivity to this parameter will be examined.
Having now defined the parameters contributing to $\mathrm{C}$ cycling in the microbial loop, the resulting steadystate equation for BP in the model is:

$$
\mathrm{BP}=\frac{\mathrm{PP}\left[\gamma+\zeta_{\mathrm{P}}+\left(1-\zeta_{\mathrm{P}}\right) \phi_{\infty}\right]}{1 / \omega-\left[\zeta_{\mathrm{B}}+\left(1-\zeta_{\mathrm{B}}\right) \phi_{\infty}\right]}
$$

where $\omega$ is the BGE. Carbon cycling through the foodweb is thus constrained using BP:PP and 6 parameters: $\omega, \phi_{1}, k_{\mathrm{C}}, \gamma, \zeta_{\mathrm{B}}$ and $\zeta_{\mathrm{P}}$. Note that in order to balance sources and sinks of C, BP:PP is expressed on an aerial basis for the entire water column, rather than more commonly presented volumetric ratios for the photic zone. The BP:PP data were selected for regions and times of year for which the steady-state assumption is appropriate. If field estimates are assigned to BP:PP and BGE, and the above estimates of $\phi_{1}, k_{\mathrm{C}}, \zeta_{\mathrm{B}}$ and $\zeta_{\mathrm{P}}$ are used, then the 1 remaining unknown, the EOC required to balance the $C$ budget (quantified by parameter $\gamma$ ), is:

$$
\gamma=\frac{\mathrm{BP}}{\mathrm{PP}}\left\{1 / \omega-\left[\zeta_{\mathrm{B}}+\left(1-\zeta_{\mathrm{B}}\right) \phi_{\infty}\right]\right\}-\zeta_{\mathrm{P}}-\left(1-\zeta_{\mathrm{P}}\right) \phi_{\infty}
$$

For completeness, the equations for zooplankton production and respiration by bacteria and zooplankton are:

$$
\begin{gathered}
\mathrm{ZP}=\left[\left(1-\zeta_{\mathrm{P}}\right) \mathrm{PP}+\left(1-\zeta_{\mathrm{B}}\right) \mathrm{BP}\right] k_{\mathrm{C}} \phi_{\infty}\left(1 / \phi_{1}-1\right) \\
\mathrm{BR}=(1-\omega) \mathrm{BP} / \omega \\
\mathrm{ZR}=\left(1-k_{\mathrm{C}}\right) \mathrm{ZP} / k_{\mathrm{C}}
\end{gathered}
$$

\section{DATA SOURCES}

Bacterial production and growth efficiency data. Three oceanic regions were selected for analysis - the northwestern Sargasso Sea, the subarctic North Pacific (SubNPac) and the central equatorial Pacific (EqPac) based on the amount of recent data available and suitability as regimes with quasi-steady state behavior (Fig. 2). Systems experiencing large seasonal accumulations of phytoplankton or bacterial biomass (e.g. North Atlantic, Ducklow et al. 1993, Li et al. 1993) were avoided. We also disregarded the EqPac in September-October 1992, for which data are available, because of the passage of a tropical instability wave that caused conditions to depart from the typical highnutrient, low-chlorophyll (HNLC) state (Archer et al. 1997). The 3 ocean regions chosen are discussed briefly below, with data summarized in Table 2 .

Primary production, which is the ultimate source of organic carbon for BP in areas remote from terrestrial inputs, occurs exclusively in the euphotic zone. A fraction of the PP is exported to depth and so BP integrated over the entire water column, rather than just the euphotic zone, should ideally be employed when studying the fate of fixed $\mathrm{C}$ and interpreting BP:PP. 
The data we employ for BP are euphotic zone integrals. Water-columnintegrated $\mathrm{BP}, \mathrm{BP}_{\mathrm{col}}$, was estimated by dividing euphotic zone $\mathrm{BP}, \mathrm{BP}_{\text {eu, }}$ by 1 minus the $f$-ratio (this ratio is the 'new' production as a fraction of total primary production; Eppley \& Peterson 1979). This calculation assumes that new production (fuelled by sources external to the euphotic zone, principally the flux of nutrients from deep water) is balanced by export of organic matter from the euphotic zone (Dugdale \& Goering 1967). The systems chosen for analysis have low $f$-ratios, such that any errors associated with this calculation are not likely to seriously affect model results.

Sargasso Sea: Data are from observations conducted between 1990 and 1998 at the Bermuda Atlantic Time Series (BATS) station (Fig. 2a; 315' N, 64 $10^{\prime} \mathrm{W}$ ) as described in Carlson et al. (1996) and available at http://www.bbsr.edu/users/ctd/. Bacterial biomass is low with no discernable seasonal variability. The longterm average BP is $36 \mathrm{mg} \mathrm{C} \mathrm{m} \mathrm{m}^{-2} \mathrm{~d}^{-1}$ (8\% of PP), based on thymidine incorporation rates and empirically determined conversion factors from the same site $(10 \mathrm{fg} \mathrm{C}$ cell $^{-1}, \quad\left[{ }^{3} \mathrm{H}\right]$-thymidine $\{\mathrm{TdR}\}$ incorporation $1.63 \times$ $10^{18}$ cells $\mathrm{mol}^{-1}$ ). The data reported in Table 2 differ from those given by Ducklow (1999) because a longer data record was included in the analysis. The mean BGE of 0.14 was determined by Carlson \& Ducklow (1996) from changes in DOC and bacterial biomass during seawater culture incubations.

Subarctic North Pacific: Data are taken from published studies by Kirchman et al. (1993) at Stn P (Fig. $2 \mathrm{~b} ; 50^{\circ} \mathrm{N}, 145^{\circ} \mathrm{W}$ ) and Sherry et al. (1999) along Line P $\left(130-145^{\circ} \mathrm{W}, 49-50^{\circ} \mathrm{N}\right.$ : see Boyd \& Harrison 1999) excluding Stn P4, which is nearest the coast.

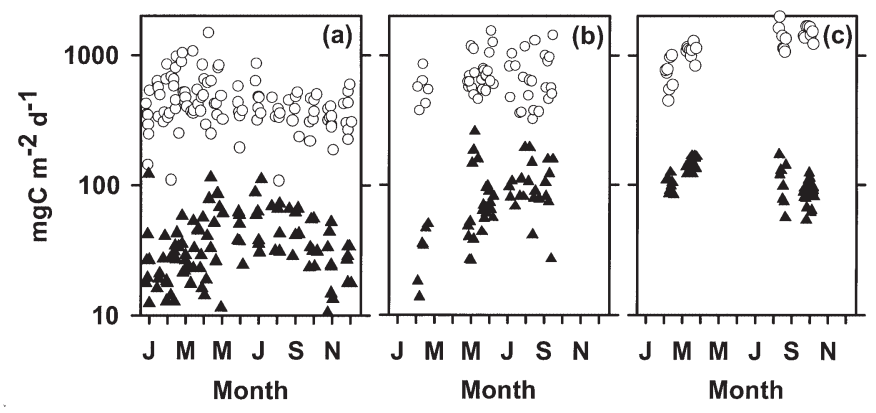

Fig. 2. Seasonal estimates of BP (solid triangles) and PP (open circles) integrated through the euphotic zone for: (a) Sargasso Sea (BATS station), (b) subarctic North Pacific (Stn P), and (c) Equatorial Pacific (EqPac time series and survey cruises). The log plots emphasize the bacterial variability
Primary production data for the earlier study are taken from Welschmeyer et al. (1993). Chlorophyll is low and seasonally stable in this classic HNLC region (Miller et al. 1991). Sporadic bacterial accumulations have been observed (Kirchman 1992), but bacterial biomass is generally uniform in this region. BP estimates are taken from thymidine and leucine incorporation rates as reported in the original studies using empirically determined conversion factors for each study. BGE estimates are provided by Sherry et al. (1999) from direct estimates of BP and BR. We use the mean of Sherry et al.'s (1999) BGE data in our analysis and the overall mean BP from Sherry et al.'s (1999) and Kirchman's (1992) studies.

Equatorial Pacific: Data are from observations made in the US JGOFS EqPac study (Fig. 2c) during the spring time series at $0^{\circ} \mathrm{N}, 140^{\circ} \mathrm{W}$ (Ducklow et al. 1995 and http://usjgofs.whoi.edu/jg/dir/jgofs/eqpac/tt008/) and from stations within $2^{\circ}$ of the equator occupied during the EqPac spring survey cruise (Kirchman et al. 1995). Bacterial biomass and chlorophyll were very uniform during the ca 2 mo observation period. Conversion factors were not determined, and so BP was originally estimated using the mean of thymidine and leucine data and the mean of factors chosen from the literature. For the present analysis, we employ the leucine data and a conversion factor value of $1.5 \mathrm{~kg} \mathrm{C} \mathrm{mol}^{-1}$ leucine incorporated (Simon \& Azam 1989, see also Ducklow et al. 2000). Using the leucine data obviates the need to employ a separate factor for C content of bacterial cells. A single experiment was performed in February 1992 to determine BGE from changes in DOC and bacterial abundance (D. L. Kirchman unpubl. data).

Primary production and $\boldsymbol{f}$-ratio. All primary production data are $24 \mathrm{~h}{ }^{14} \mathrm{C}$ incubations, either in situ (Kirchman et al. 1993, Carlson et al. 1996) or under screens providing light and temperature conditions from which water samples were taken (Boyd \& Harrison 1999). Estimates of the $f$-ratio are variable depending on the methodologies used. We use an $f$-ratio of 0.21 for the 
Sargasso Sea, as predicted by Doney et al.'s (1996) model of the BATS station. Wheeler \& Kokkinakis (1990) provide seasonal estimates of $f$-ratios between 0.25 and 0.41 in the SubNPac, with a mean of 0.36. Finally McCarthy et al. (1996) give a mean $f$-ratio of 0.11 for $2^{\circ} \mathrm{N}$ to $2^{\circ} \mathrm{S}$ in the EqPac.

BP:PP were analyzed by calculating each individual euphotic zone BP:PP ratio and transforming the resulting proportions using the arcsin transformation (Sokal \& Rohlf 1981). All the BP:PP values fell between 0 and 1 , making the arcsin transformation appropriate for these data. The resulting means and standard deviations are given in Table 2 .

\section{RESULTS}

Variation of predicted BP:PP in response to BGE is shown in Fig. 3, for PER = 0, 10, 20, and 40\%. Sensitivity of the solutions to parameters associated with grazer recycling of carbon $\left(\phi_{1}, k_{\mathrm{C}}\right)$, a key process (see below), is shown. The field data (Table 2) are superimposed. Predicted BP:PP increases markedly with increasing BGE and PER. The Sargasso Sea and SubNPac data points are embraced by low-PER $(\leq 20 \%)$ solutions, whereas the EqPac data point is not within the range of model solutions even when PER is as high as $40 \%$ (for $\phi_{1}=0.3, k_{C}=0.36$, a PER of $54 \%$ is required to balance the $\mathrm{C}$ demand). Model solutions are generally consistent with a combination of low BP:PP (0.1 to $0.15)$, low $B G E(<0.3)$ and low PER, which may occur in many ocean environments.

Model solutions were derived for each of the 3 ocean areas by using BGE as in Table $2, \phi_{1}, k_{\mathrm{C}} \zeta_{\mathrm{B}}$ and $\zeta_{\mathrm{P}}$ as in Table 1, and adjusting phytoplankton excretion of EOC (parameter $\gamma$, Eq. 3) to achieve observed $\mathrm{BP}_{\text {col }} \mathrm{PP}$ (Table 2). Details of the resulting solutions for each site, along with a parameter sensitivity analysis of the Sargasso Sea solution, are shown in Fig. 4. The resulting PER of $54 \%$ required to sustain BP:PP of 0.15 at EqPac appears unrealistic given that PER is usually less than $20 \%$ (Nagata 2000), although PER as high as (a) $\mathrm{PER}=0$

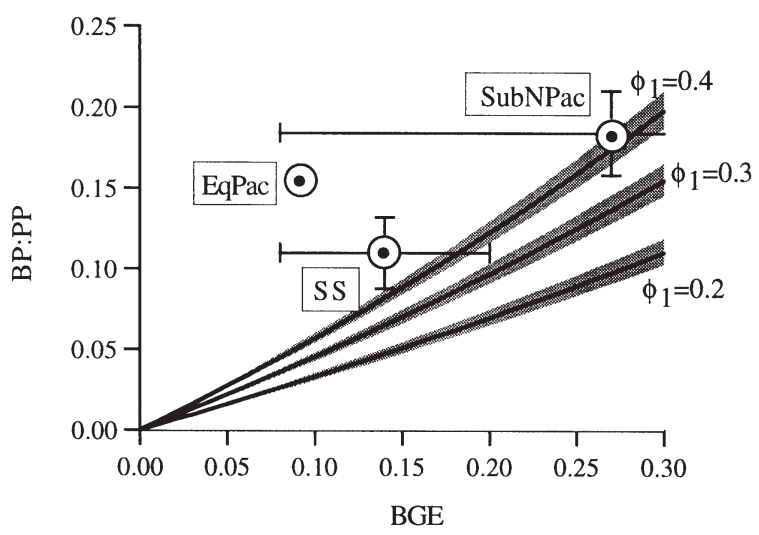

(c) $\mathrm{PER}=20 \%$

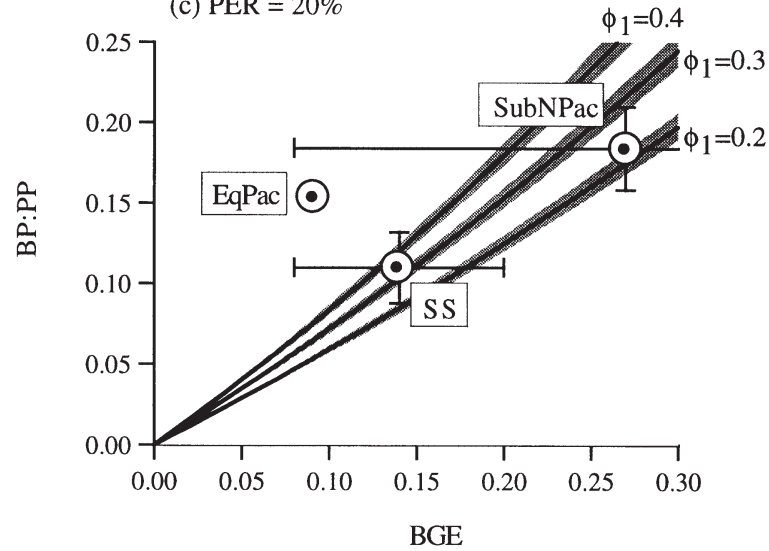

(b) $\mathrm{PER}=10 \%$

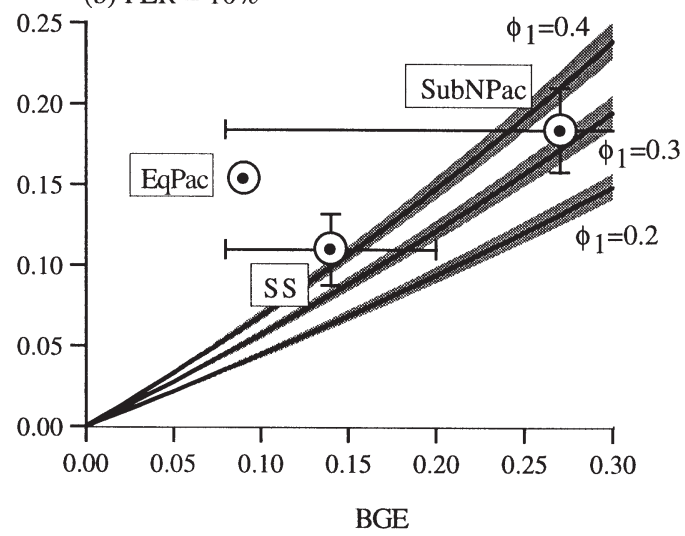

(d) $\mathrm{PER}=40 \%$

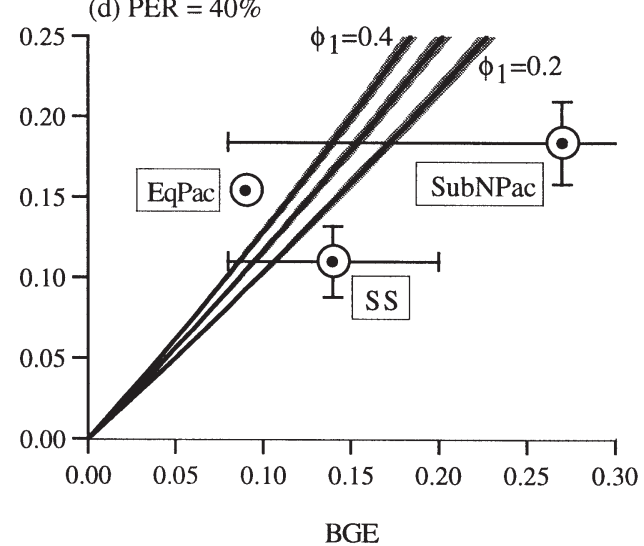

Fig. 3. Predicted BP:PP vs BGE, for $\phi_{1}=0.2,0.3,0.4$ and PER $=0,10,20,40 \%$. Shaded areas indicate sensitivity to $k_{\mathrm{C}}$, varied between 0.29 and 0.43. Water-column-integrated BP:PP and BGE for ocean sites (Table 2) superimposed; SS: Sargasso Sea, Sub NPac: subarctic North Pacific, EqPac: equatorial Pacific 
$40 \%$ may be possible, particularly in oligotrophic conditions (Karl et al. 1998, Teira et al. 2001). Attention should therefore be focused on the low-PER solutions of the other 2 sites. Model solutions for observed BP:PP required PERs of 13 and $23 \%$ for the SubNPac and the Sargasso Sea respectively. Higher BP:PP in the SubNPac relative to the Sargasso Sea is consistent with it should be noted that there is a large uncertainty in the SubNPac BGE.

Organic carbon is supplied to the DOC pool either via autotrophs (EOC, phytoplankton grazing and lysis) or after having been cycled at least once by bacteria (bacterial grazing, lysis). Results indicate that grazing of phytoplankton is the major supply route of DOC to fuel BP, although EOC release by phytoplankton is also a significant source. Supply of DOC via bacterial grazing and lysis contributes little to the overall $\mathrm{C}$ budget, because bacteria are inefficient (low BGE) and hence only a small fraction of DOC consumed by bachigher estimated BGE at the former (Table 2), although

teria becomes available for reprocessing. Model results are thus insensitive to parameter $\zeta_{\mathrm{B}}$ (lysis of bacteria), despite it being assigned a relatively high value. In essence, bacterial recycling of DOC supplies only a small part of the $\mathrm{C}$ flow through the microbial loop. The model is moderately sensitive to parameters associated with the direct supply route, namely $\phi_{1}, k_{\mathrm{C}}$ and $\gamma_{1}$ but not $\zeta_{\mathrm{P}}$. BR and ZR are predicted to be broadly similar in magnitude as sinks for organic $C_{\text {, except when }}$ parameters $\phi_{1}$ and $k_{\mathrm{C}}$ are doubled (see tabulated results in Fig. 4).

\section{DISCUSSION}

The model provides a means of studying $\mathrm{C}$ flow through the microbial loop as well as a focus for understanding and constraining acceptable estimates of BP and BGE. Model-data mismatches (notably EqPac) may be due to either inaccuracies in the estimates of BP:PP and BGE or problems associated with the assumptions and parameterization of the model.

\section{Data uncertainties}

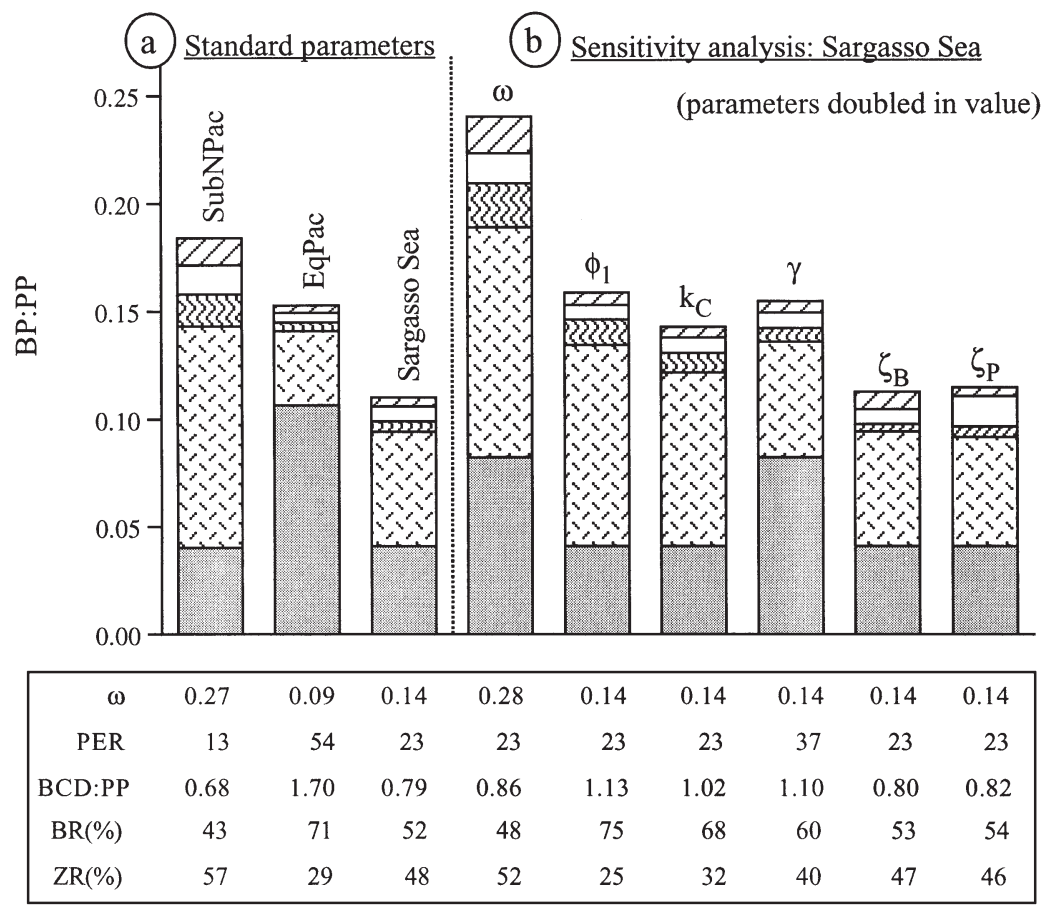

Fig. 4. Characteristics of model output. (a) Solutions for the SubNPac, EqPac, and Sargasso Sea using standard parameters (BP:PP and BGE from Table 2, $\gamma$ fitted and remaining parameters from Table 1). (b) Sensitivity analysis of the Sargasso Sea solution, showing the effect of doubling each model parameter in turn. Stacked bars indicate relative source terms of DOM for BP. The table shows the corresponding key parameters $\omega$ and PER, and resulting BCD:PP and respiration values for each scenario
Accurate estimates of $\mathrm{BP}$ and $\mathrm{BGE}$ are difficult to obtain because they rely on measurements of related processes (e.g. nucleic acid precursor incorporation) rather than those of production rates or mass accumulation per se. BP estimates thus depend on, and are functions of, conversion factors (CF) (Ducklow 2000). Our estimates for the Sargasso Sea and SubNPac utilized the actual CF values determined during the cited studies, which might increase our confidence in the data. No CF values were determined for EqPac, and even though a lower set of BP estimates was employed for this new analysis, model analyses indicate that the actual BP might still be even lower (see discussion below and Fig. 3). Interestingly, the raw thymidine and leucine incorporation rates for the spring time series cruise were higher than the other 3 periods of occupation at the EqPac station (Ducklow et al. 1995). It may be that these observations were made during an anomalous period, when a different mix of cycling processes was controlling DOC flux. 
BGE estimates depend on prolonged incubations in order to boost detection of DOC utilization and increasing bacterial abundance. Such experiments are prone to bottle containment artifacts as well as the same uncertainties which complicate BP estimates (del Giorgio \& Cole 1998). Removal of bacteria by viruses and grazers may act to lower the BGE estimates in longer incubations. While efforts were made to limit incubations to reliable intervals, it is possible that our lone EqPac datum in particular may be too low. It was made during the 1991-92 El Niño in very warm $\left(28^{\circ} \mathrm{C}\right)$ water. Bottle artifacts might be more probable in warmer samples when temperature-dependent processes are faster.

The ${ }^{14} \mathrm{C}$ primary production data presented herein are taken to represent net synthesis of particulate matter such that EOC release by phytoplankton is an extra contribution to total net production. Several recent studies have suggested that significant amounts of this extra DOC may be adsorbed to the GF/F filters used to harvest the incubations (Maske \& Garcia-Mendoza 1994, Karl et al. 1998, Morán et al. 1999). ${ }^{14} \mathrm{C}$ incubations may therefore overestimate particulate primary production both because it measures something between net and gross production and because of DOC adsorption to filters. If ${ }^{14} \mathrm{C}$ measurements approximate gross production, then respiration by phytoplankton is an additional $\mathrm{C}$ sink which requires attention, and so higher PERs than are currently indicated by the model would be needed to supply sufficient DOC to generate observed BP:PP ratios. In contrast if ${ }^{14} \mathrm{C}$ estimates include DOC adsorption to filters, then DOC will be supplied in greater quantity to bacteria than is predicted by the model, because EOC is a direct supply route to bacteria, and less additional $\mathrm{C}$ has then to be found to balance sources and sinks in the system (although PER may be high).

\section{Steady-state assumption}

The chosen ocean locations are all characterized by high recycling and low $f$-ratio (Wheeler \& Kokkinakis 1990, Doney et al. 1996, McCarthy et al. 1996), with grazers being tightly coupled to primary producers (Landry et al. 1997, Rivkin et al. 1999), and may therefore be reasonably approximated assuming steadystate conditions. Data for systems characterized by strong seasonality, such as the North Atlantic and Arabian Sea, were avoided. There is nevertheless considerable variability in $\mathrm{BP}$ and $\mathrm{PP}$ at the 3 chosen sites (Fig. 2, Table 2). The quasi-steady-state behavior seen in standing stocks is only a dynamic equilibrium, while rate processes vary more widely. Both the BATS station and Stn P have well-known seasonal increases in PP, with phytoplankton stocks held in check by rapid grazer response to increased growth. It follows that the flux of DOC from phytoplankton and zooplankton would also increase seasonally. It may be that the annual period is too long for one single scenario to fit the data. On the other hand, variability was low for the EqPac data set (coefficients of variation ca $10 \%$ for PP and $\mathrm{BP}$ ), but these data alone do not fit within our model solutions. This problem may be a consequence of using a single BGE estimate, or inappropriate conversion factors for deriving BP. Either a higher BGE or a lower BP would move the EqPac point toward the model solutions, but a rather high PER would still be required in most cases.

Locally produced DOC, the primary source for bacterial nutrition, can depart from steady-state behavior. Accumulation of semi-labile DOC during spring will tend to produce low BP:PP during that period and high BP:PP later in the year as the accumulated material is degraded and consumed by bacteria. We purposefully avoided systems characterized by large seasonal accumulations in DOC. In the model all DOC is assumed to be of autochthonous origin. Open ocean ecosystems have open boundaries and so are not necessarily in organic balance. It has been calculated (del Giorgio et al. 1997) that in environments where rates of photosynthesis are low, respiration exceeds photosynthesis, resulting in organic carbon deficit. However, Williams (1998) analyzed depth-integrated measures of production and respiration in the open oceans and concluded that production generally exceeds respiration in the upper $100 \mathrm{~m}$ of the water column, which is consistent with findings from earlier mass-balance calculations (Smith \& Mackenzie 1987) that the open oceans as a whole are not substantially out of organic C balance.

\section{Carbon cycling}

Predicted C cycling in the model appears to be generally consistent with the field estimates of BP:PP and BGE, particularly for the Sargasso Sea and SubNPac, despite the uncertainties in both model and data. High EOC release is generally associated with oligotrophy (e.g. Obernosterer \& Herndl 1995, Petit et al. 1999, Teira et al. 2001), although the mechanisms underlying this response are not fully understood. The small cells which tend to dominate in oligotrophic systems may exhibit high DOC release because of high metabolism (Malinsky-Rushansky \& Legrand 1996) or high leakage due to a large surface area per unit volume (Bjørnsen 1988, Hasegawa et al. 2000). High BP:PP ratios subsidized by EOC might therefore be expected in oligotrophic systems. Carbon cycling in the Sargasso Sea is balanced in the model with a PER of $23 \%$, i.e. 
our analysis provided no indication of a particularly high PER requirement in this predominantly, although not persistently, oligotrophic environment.

BGE varies systematically with BP and the trophic richness of the ecosystem (del Giorgio \& Cole 1998) with low values associated with the most dilute oligotrophic systems. Del Giorgio \& Cole (1998) showed that BGE associated with EOC is typically 0.6, based on published data of BGE for organic matter grouped according to source. This high BGE is probably due to simple sugars which can be easily hydrolyzed and consumed by bacteria, in contrast to complex biomolecules characterized by bonding structures which require exhaustive hydrolysis before uptake can occur ('labile' vs 'semi-labile' DOC, e.g. Anderson \& Williams 1999). BGE may therefore be expected to be greatest in environments where PER is highest. Low BGE in low-nutrient environments may be a result of high cell-specific maintenance requirements; although BR and BP are correlated, the variation of BR tends to be considerably more conservative (Roland \& Cole 1999). It is notable that the tabulated BGE estimate for the highly productive EqPac site is lower than the Sargasso Sea estimate, and very much less than that of the SubNPac. This line of reasoning suggests that the EqPac BGE of 0.09 may be an underestimate, which could be a major factor contributing to the inability of the model to reconcile it with a BP:PP of 0.153. Increasing BGE to a mean ocean value of 0.15 (del Giorgio \& Cole 2000) would still require a PER of $34 \%$ to achieve BP:PP of 0.153 .

Phytoplankton are the ultimate source of organic C supplied to the ocean ecosystem. A fraction of primary production directly supplies the DOC pool, via either EOC, grazing by zooplankton or phytoplankton lysis. Remaining fluxes to the DOC pool are of material that has traveled at least once through the bacterial node in the microbial loop. In the systems studied, characterized by low BGE, BCD is primarily influenced by parameters related to the direct supply route, i.e. phytoplankton loss terms and EOC (notably parameters $\phi_{1}$, $k_{\mathrm{C}} \gamma$ ), but not BGE, although BP is of course sensitive to BGE. The sensitivity analysis illustrates this point: doubling BGE for the Sargasso Sea scenario causes only a small increase in BCD:PP (0.79 to 0.86) due to extra recycling, whereas BP:PP more than doubles $(0.11$ to 0.24 ). Our analysis indicates that zooplankton processes are a major supply route of DOC in marine systems, as has been previously suggested (Jumars et al. 1989 , Nagata 2000). Although only $30 \%$ of organic C is passed to DOC during any one grazing event $\left(\phi_{1}=0.3\right)$, the total carbon fraction passed to the DOC pool is increased as material passes along the modeled chain of infinite grazers, e.g. the fraction is $40 \%$ (i.e. $\phi_{\infty}=0.4$ ) when $k_{\mathrm{C}}$ is 0.36 . The trophic structure of the whole food web should therefore be considered when examining C fluxes to the microbial loop. Although low PER appears to be a feature of many ocean systems, phytoplankton exudation is important regarding BP because cycling processes do not act on it before it is used by bacteria. So, for example, our analysis of the Sargasso Sea indicates that a PER of $23 \%$ supplies $37 \%$ of the BCD.

Viruses are the major agents of mortality in bacteria (Proctor \& Fuhrman 1990). Predicted fluxes of DOC via viral lysis and bacterivory are, however, a low fraction of the total $\mathrm{C}$ budget because most organic $\mathrm{C}$ is respired by bacteria and not converted to biomass (low $\mathrm{BGE}$ ), and so bacteria loss terms (grazing and lysis) contribute a relatively small fraction of BCD and hence $\mathrm{BP}$. This is not to say that viral lysis of bacteria is unimportant in ecosystem dynamics, only that it is not a major term in the flow of $\mathrm{C}$ through the microbial loop, unless BGE is high. Perhaps surprisingly, the model was relatively insensitive to viral lysis of phytoplankton, a direct supply route from autotrophs to DOC. The products of viral lysis pass entirely into the DOC pool in the model, and so solutions which include this process should therefore have elevated BP:PP in comparison to solutions with grazing as the sole means of cycling particulate organic matter. The magnitude of phytoplankton lysis in natural systems is poorly known. The available evidence would suggest that it is relatively low, hence our default setting for parameter $\zeta_{\mathrm{P}}$ of 0.05 . Increasing this value to a much higher value would have a significant impact on BP:PP, e.g. raising $\zeta_{\mathrm{P}}$ to 0.5 causes the predicted BP:PP for the Sargasso Sea to increase by $37 \%$ from the 0.110 ratio of the standard run. Further research is needed to assess the magnitude of this process in natural systems.

ZR is predicted to be a major organic matter sink, similar in magnitude to BR. Our analysis that bacteria are a major sink for primary production is shown to be consistent with the best estimates of BGE and DOM production by zooplankton and phytoplankton. Recent measurements of community respiration in the Arabian Sea and coastal Antarctic waters (Robinson \& Williams 1999, Robinson et al. 1999) indicate that BR is typically 10 to $20 \%$ of the total and microzooplankton respiration is somewhat higher (20 to $40 \%$ ). However these 2 regimes are known to be characterized by a dominance of larger zooplankton (Longhurst \& Harrison 1989) and by non-steady state conditions, so they may differ from the oceanic regimes considered here. Other estimates of the contribution of BR to community respiration include values around 40 to $50 \%$ (e.g. Biddanda et al. 1994, Williams 2000). Rivkin \& Legendre (2001) derived a relationship between BGE and temperature and used it to calculate BR from BP. Using this method they found a close correlation between BR and community respiration in marine systems, suggesting 
BR to be the dominant component. Further insight into $\mathrm{C}$ cycling through microbial food webs will be gained as more size-fractionated community respiration measurements are made.

\section{Utility of simple ratios}

The ideal measure of bacteria as a sink for organic C is BR as a fraction of total net primary production, i.e. BR:PP $(1+\gamma)$, which at steady state cannot exceed 1.0. However the ratio most commonly encountered in the literature is to divide BP:PP by BGE, giving BCD:PP. This ratio should be interpreted carefully as a measure of the microbial loop as a pathway for primary production, as BCD is itself unconstrained by PP due to recycling of DOC, and no account is taken of production of EOC by phytoplankton. Note, for example, that BCD:PP exceeded 1.0 in 4 of the model solutions presented in Fig. 4, despite there being no allochthonous subsidy of DOC in the model. BCD:PP will overestimate BR:PP $(1+\gamma)$, because BCD is greater than BR and $\mathrm{PP}$ less than $\mathrm{PP}(1+\gamma)$. The 2 ratios are easily interconverted if $\omega$ and $\gamma$ are known:

$$
\mathrm{BR}: \mathrm{PP}(1+\gamma)=\frac{(1-\omega) \mathrm{BCD}}{(1+\gamma) \mathrm{PP}}
$$

The quotient $(1+\gamma) /(1-\omega)$, which is the factor by which BCD:PP overestimates BR:PP $(1+\gamma)$, is shown for PER 0 to $40 \%$ and various BGE in Fig. 5. Note that the $\omega=0$ line (dashed) gives the error remaining after the $(1-\omega)$ correction to convert BCD to BR, but without the $(1+\gamma)$ adjustment. At low PER the error is then relatively small, whereas if the $(1-\omega)$ correction is not made the error increases rapidly with increasing $\omega$,

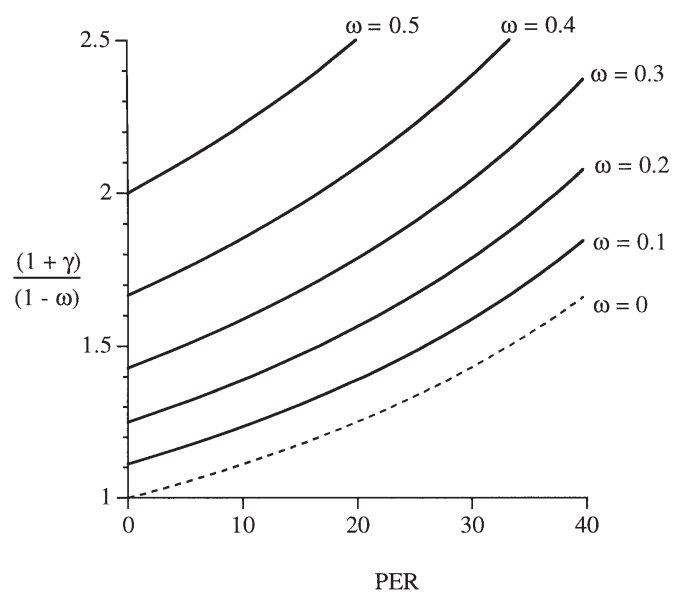

Fig. 5. Ratio by which BCD:PP overestimates BR:PP $(1+\gamma)$ for a PER of $0-40 \%$ and a BGE of $0-0.5$. The $\omega=0$ line (dashed) indicates the overestimation if the BGE correction is made, i.e. $\mathrm{BR}=(1-\omega) \mathrm{BCD}$, leaving only the $\gamma$ correction because the extent to which BCD overestimates BR is inversely proportional to $\omega$. It is perhaps surprising that the often-measured and highly useful BP:PP ratio is not commonly multiplied by the quotient $(1-\omega) / \omega$ to give $\mathrm{BR}: \mathrm{PP}$, rather than $1 / \omega$ to give $\mathrm{BCD}: \mathrm{PP}$, when examining $\mathrm{C}$ flow through microbial food webs. The $(1+\gamma)$ correction is more difficult to address because phytoplankton EOC release is not well understood. For low PER the error is small. An important feature of the model presented here is that it permits $\gamma$ to be estimated (Eq. 3).

\section{CONCLUSIONS}

Our model was applied to oceanic regimes for which relatively large amounts of bacterial production (BP) data already exist, but it is worth noting again that there are still only few observations of oceanic BP compared to inshore systems, where allochthonous DOC inputs subsidize bacterial processes. Past reviews indicate that BP is roughly 20 to $30 \%$ of local particulate primary production (PP), a fraction our analysis suggests is somewhat too high for offshore systems in which bacteria rely entirely on autochthonous DOC sources. Our results are consistent with the hypothesis that at least under near-steady state conditions BP is about 10 to $15 \%$ of PP in the open sea. This low fraction is necessitated by: (1) the absolute constraint that BR does not exceed the input of DOC from local processes; and (2) observations that bacterial growth efficiency (BGE) tends to be low. Both $\mathrm{BP}$ and $\mathrm{BGE}$ remain hard to quantify accurately (there is no authentic standard for any bacterial property) and depend critically on assumed or measured values of conversion factors (CF). Our model provides a tool for examining the reliability of $\mathrm{BP}$ estimates and revising $\mathrm{CF}$ values if, for example, published values were employed in place of empirical determinations. Our results show that the BP estimates for the Sargasso Sea and Subarctic North Pacific, based on empirical $\mathrm{CF}_{\text {, }}$ are consistent with reasonable scenarios for $\mathrm{C}$ cycling at these sites. In contrast, mismatch between data and model for the equatorial Pacific site suggests that the estimated BP or $B G E$, or both, may have been in error. Overall however, all our findings for the 3 systems considered here support the conclusion that oceanic systems are generally characterized by low PER (percentage of extracellular release), BP and BGE. Low PER gives rise to zooplankton-related processes supplying the dominant share of DOC for bacterial consumption. Thus net DOC production and BP might be low in systems where or when grazing activity is minimal (Carlson et al. 1998). Both bacterial and zooplankton respiration are major $\mathrm{C}$ sinks. 
Acknowledgements. T.R.A. is supported by the UK Natural Environment Research Council. T.R.A. and H.W.D. are funded as part of the US JGOFS Synthesis and Modeling Program (SMP) through NSF Grant OCE 9819581. We wish to thank C. M. Turley (Plymouth Marine Laboratory) for productive discussions regarding the work, 3 anonymous referees and M. Church for comments on the manuscript, and D. Kirchman (University of Delaware) and N. Sherry (University of British Columbia) for providing SubNPac BP data used in our analysis. This is US JGOFS contribution number 587.

\section{LITERATURE CITED}

Anderson TR (1994) Relating C:N ratios in zooplankton food and faecal pellets using a biochemical model. J Exp Mar Biol Ecol 184:183-199

Anderson TR, Williams PJleB (1998) Modelling the seasonal cycle of dissolved organic carbon at Station $\mathrm{E}_{1}$ in the English Channel. Estuar Coastal Shelf Sci 46:93-109

Anderson TR, Williams PJleB (1999) A one-dimensional model of dissolved organic carbon cycling in the water column incorporating combined biological-photochemical decomposition. Global Biogeochem Cycles 13:337-349

Archer D, Aiken J, Balch W, Barber R and 13 others (1997) A meeting place of great ocean currents: shipboard observations of a convergent front at $2^{\circ} \mathrm{N}$ in the Pacific. Deep-Sea Res II 44:1827-1849

Azam F, Smith DC, Steward GF, Hagström Å (1994a) Bacteria-organic matter coupling and its significance for oceanic carbon cycling. Microb Ecol 28:167-179

Azam F, Steward GF, Smith DC, Ducklow HW (1994b) Significance of bacteria in the carbon fluxes of the Arabian Sea. Proc Indian Academy of Sciences. Earth Planet Sci 103: 341-351

Banse K (1992) Grazing, temporal changes of phytoplankton concentrations, and the microbial loop in the open sea. In: Falkowski PG, Woodhead AD (eds) Primary productivity and biogeochemical cycles in the sea. Plenum Press, New York, p 409-440

Biddanda B, Opsahl S, Benner R (1994) Plankton respiration and carbon flux through bacterioplankton on the Louisiana shelf. Limnol Oceanogr 39:1259-1275

Bjørnsen PK (1988) Phytoplankton exudation of organic matter: why do healthy cells do it? Limnol Oceanogr 33: $151-154$

Børsheim KY (2000) Bacterial production rates and concentrations of organic carbon at the end of the growing season in the Greenland Sea. Aquat Microb Ecol 21:115-123

Boyd PW, Harrison PJ (1999) Phytoplankton dynamics in the NE subarctic Pacific. Deep-Sea Res II 46:2405-2432

Carlson CA, Ducklow HW (1996) Growth of bacterioplankton and consumption of dissolved organic carbon in the Sargasso Sea. Aquat Microb Ecol 10:69-85

Carlson CA, Ducklow HW, Sleeter TD (1996) Stocks and dynamics of bacterioplankton in the northwestern Sargasso Sea. Deep-Sea Res II 43:491-515

Carlson CA, Ducklow HW, Smith WO, Hansell DA (1998) Carbon dynamics during spring blooms in the Ross Sea polynya and the Sargasso Sea: contrasts in dissolved and particulate organic carbon partitioning. Limnol Oceanogr 43:375-386

Cho BC, Azam F (1988) Major role of bacteria in biogeochemical fluxes in the ocean's interior. Nature 332:441-443

Cole JJ, Pace ML, Findlay S (1988) Bacterial production in fresh and saltwater ecosystems: a cross-system overview. Mar Ecol Prog Ser 43:1-10
Conan P, Turley C, Stutt E, Pujo-Pay M, van Wambeke F (1999) Relationship between phytoplankton efficiency and the proportion of bacterial production to primary production in the Mediterranean Sea. Aquat Microb Ecol 17: 131-144

Dam HG, Miller CA, Jonasdottir SH (1993) The trophic role of mesozooplankton at $47^{\circ} \mathrm{N}, 20^{\circ} \mathrm{W}$ during the North Atlantic Bloom Experiment. Deep-Sea Res II 40:197-212

del Giorgio PA, Cole JJ (1998) Bacterial growth efficiency in natural aquatic systems. Annu Rev Ecol Syst 29:503-541

del Giorgio PA, Cole JJ (2000) Bacterial energetics and growth efficiency. In: Kirchman DL (ed) Microbial ecology of the oceans. Wiley-Liss, New York, p 289-325

del Giorgio PA, Cole JJ, Cimbleris A (1997) Respiration rates in bacteria exceed phytoplankton production in unproductive aquatic systems. Nature 385:148-151

Doney SC, Glover DM, Najjar RG (1996) A new coupled, onedimensional biological-physical model for the upper ocean: applications to the JGOFS Bermuda Atlantic Timeseries Study (BATS) site. Deep-Sea Res II 43:591-624

Ducklow HW (1999) The bacterial component of the oceanic euphotic zone. FEMS Microbiol Ecol 30:1-10

Ducklow HW (2000) Bacterial production and biomass in the oceans. In: Kirchman DL (ed) Microbial ecology of the oceans. Wiley-Liss, New York, p 85-120

Ducklow HW, Kirchman DL, Quinby HL, Carlson CA, Dam HG (1993) Stocks and dynamics of bacterioplankton carbon during the spring phytoplankton bloom in the eastern North Atlantic Ocean. Deep-Sea Res 40:245-263

Ducklow HW, Quinby HL, Carlson CA (1995) Bacterioplankton dynamics in the equatorial Pacific during the $1992 \mathrm{El}$ Niño. Deep-Sea Res II 42:621-638

Ducklow HW, Dickson ML, Kirchman DL, Steward G, Orchardo J, Marra J, Azam F (2000) Constraining bacterial production, conversion efficiency and respiration in the Ross Sea, Antarctica, January-February, 1997. Deep-Sea Res II 47:3227-3247

Dugdale RC, Goering JJ (1967) Uptake of new and regenerated forms of nitrogen in primary productivity. Limnol Oceanogr 12:196-206

Eppley RW, Peterson BJ (1979) Particulate organic matter flux and planktonic new production in the deep ocean. Nature 282:677-680

Eppley RW, Sloan PR (1965) Carbon balance experiments with marine phytoplankton. J Fish Res Bd Can 22: 1083-1097

Fasham MJR, Ducklow HW, McKelvie SM (1990) A nitrogenbased model of plankton dynamics in the oceanic mixed layer. J Mar Res 48:591-639

Fuhrman JA (1999) Marine viruses and their biogeochemical and ecological effects. Nature 399:541-548

Fuhrman JA (2000) Impact of viruses on bacterial processes. In: Kirchman DL (ed) Microbial ecology of the oceans. Wiley-Liss, New York, p 327-350

Gobler CJ, Hutchins DA, Fisher NS, Cosper EM, SanudoWilhelmy SA (1997) Release and bioavailability of C, N, P, $\mathrm{Se}$, and Fe following viral lysis of a marine chrysophyte. Limnol Oceanogr 42:1492-1504

Hasegawa T, Koike I, Mukai H (2000) Release of dissolved organic nitrogen by size-fractionated natural planktonic assemblages in coastal waters. Mar Ecol Prog Ser 198: $43-49$

Hassett RP, Landry MR (1988) Short-term changes in feeding and digestion by the copepod Calanus pacificus. Mar Biol 99:63-74

Jahnke RA, Craven DB (1995) Quantifying the role of heterotrophic bacteria in the carbon cycle: a need for respiration 
rate measurements. Limnol Oceanogr 40:436-441

Jumars PA, Penry DL, Baross JA, Perry MJ, Frost BW (1989) Closing the microbial loop: dissolved carbon pathway to heterotrophic bacteria from incomplete ingestion, digestion and absorption in animals. Deep-Sea Res 36:483-495

Karl DM, Hebel DV, Björkman K, Letelier RM (1998) The role of dissolved organic matter release in the productivity of the oligotrophic North Pacific Ocean. Limnol Oceanogr 43:1270-1286

Kirchman DL (1992) Incorporation of thymidine and leucine in the subarctic Pacific: application to estimating bacterial production. Mar Ecol Progr Ser 82:301-309

Kirchman DL, Keil RG, Simon M, Welschmeyer NA (1993) Biomass and production of heterotrophic bacterioplankton in the oceanic subarctic Pacific. Deep-Sea Res I 40: 967-988

Kirchman DL, Rich JH, Barber RT (1995) Biomass and biomass production of heterotrophic bacteria along $140 \mathrm{~W}$ in the equatorial Pacific: effect of temperature on the microbial loop. Deep-Sea Res II 42:603-619

Lampert W (1978) Release of dissolved organic carbon by grazing zooplankton. Limnol Oceanogr 23:831-834

Lampitt RS, Noji T, von Bodungen B (1990) What happens to zooplankton faecal pellets? Implications for material flux. Mar Biol 104:15-23

Landry MR, Barber RT, Bidigare RR, Chai R and 9 others (1997) Iron and grazing constraints on primary production in the central equatorial Pacific: an EqPac synthesis. Limnol Oceanogr 42:405-418

Langdon C, Marra J, Knudson C (1995) Measurements of net and gross $\mathrm{O}_{2}$ production, dark $\mathrm{O}_{2}$ respiration, and ${ }^{14} \mathrm{C}$ assimilation at the Marine Light-Mixed Layers site $\left(59^{\circ} \mathrm{N}\right.$, $21^{\circ} \mathrm{W}$ ) in the northwest Atlantic Ocean. J Geophys Res 100:6645-6653

Le Borgne R (1982) Zooplankton production in the eastern tropical Atlantic Ocean: net growth efficiency and P:B in terms of carbon, nitrogen, and phosphorus. Limnol Oceanogr 27:681-698

Li WKW, Dickie PM, Harrison WG, Irwin BD (1993) Biomass and production of bacteria and phytoplankton during the spring bloom in the western North Atlantic Ocean. DeepSea Res II 40:307-329

Longhurst AR, Harrison WG (1989) The biological pump: profiles of plankton production and consumption in the upper ocean. Prog Oceanogr 22:47-123

Malinsky-Rushansky NZ, Legrand C (1996) Excretion of dissolved organic carbon by phytoplankton of different sizes and subsequent bacterial uptake. Mar Ecol Prog Ser 132: 249-255

Maske H, Garcia-Mendoza E (1994) Adsorption of dissolved organic matter to the inorganic filter substrate and its implications for ${ }^{14} \mathrm{C}$ uptake measurements. Appl Environ Microbiol 60:3887-3889

McCarthy JJ, Garside C, Nevins JL, Barber RT (1996) New production along $140^{\circ} \mathrm{W}$ in the equatorial Pacific during and following the 1992 El Niño event. Deep-Sea Res II 43: 1065-1093

Miller CB, Frost BW, Wheeler PA, Landry MR, Welschmeyer N, Powell TM (1991) Ecological dynamics in the subarctic Pacific, a possibly iron-limited ecosystem. Limnol Oceanogr 36:1600-1615

Møller EF, Nielsen TG (2000) Plankton community structure and carbon cycling off the western coast of Greenland, with emphasis on sources of DOM for the bacterial community. Aquat Microb Ecol 22:13-25

Morán XAG, Gasol JM, Arin L, Estrada M (1999) A comparison between glass fiber and membrane filters for the estimation of phytoplankton POC and DOC production. Mar Ecol Prog Ser 187:31-41

Nagata T (2000) Production mechanisms of dissolved organic matter. In: Kirchman DL (ed) Microbial ecology of the oceans. Wiley-Liss, New York, p 121-152

Obernosterer I, Herndl GJ (1995) Phytoplankton extracellular release and bacterial growth: dependence on the inorganic N:P ratio. Mar Ecol Prog Ser 116:247-257

Pedrós-Alió C, Calderón-Paz JI, Guixa-Boixereu N, Estrada M, Gasol JM (1999) Bacterioplankton and phytoplankton biomass and production during summer stratification in the northwestern Mediterranean Sea. Deep-Sea Res I 46: 985-1019

Petit M, Alves GP, Lavandier P (1999) Phytoplanktonic exudation, bacterial reassimilation and production for three diel cycles in different trophic conditions. Arch Hydrobiol 146: 285-309

Proctor LM, Fuhrman JA (1990) Viral mortality of marine bacteria and cyanobacteria. Nature 343:60-62

Rivkin RB, Legendre L (2001) Biogenic carbon cycling in the upper ocean: effects of microbial respiration. Science 291: 2398-2400

Rivkin RB, Putland JN, Anderson MR, Deibel D (1999) Microzooplankton bacterivory and herbivory in the NE subarctic Pacific. Deep-Sea Res II 46:2579-2618

Robinson C, Williams PJleB (1999) Plankton net community production and dark respiration in the Arabian Sea during September 1994. Deep-Sea Res II 46:745-765

Robinson C, Archer SD, Williams PJleB (1999) Microbial dynamics in coastal waters of East Antarctica: plankton production and respiration. Mar Ecol Prog Ser 180:23-36

Roland F, Cole JJ (1999) Regulation of bacterial growth efficiency in a large turbid estuary. Aquat Microb Ecol 20: $31-38$

Sherry ND, Boyd PW, Sugimoto K, Harrison PJ (1999) Seasonal and spatial patterns of heterotrophic bacterial production, respiration, and biomass in the subarctic NE Pacific. Deep-Sea Res II 46:2557-2578

Shiah FK, Ducklow HW (1997) Bacterioplankton growth responses to temperature and chlorophyll variations in estuaries measured by thymidine:leucine incorporation ratio. Aquat Microb Ecol 13:151-159

Simon M, Azam F (1989) Protein content and protein synthesis rates of planktonic marine bacteria. Mar Ecol Prog Ser 51:201-213

Smith DC, Simon M, Alldredge AL, Azam F (1992) Intense hydrolytic enzyme activity on marine aggregates and implications for rapid particle dissolution. Nature 359: 139-142

Smith SV, Mackenzie FT (1987) The oceans as a net heterotrophic system: implications from the carbon biogeochemical cycle. Global Biogeochem Cycles 1:187-198

Sokal RR, Rohlf FJ (1981) Biometry, 2nd edn. Freeman, New York

Straile D (1997) Gross growth efficiencies of protozoan and metazoan zooplankton and their dependence on food concentration, predator-prey weight ratio, and taxonomic group. Limnol Oceanogr 42:1375-1385

Strayer DL (1988) On the limits to secondary production. Limnol Oceanogr 33:1217-1220

Strom SL, Benner R, Dagg MJ (1997) Planktonic grazers are a potentially important source of marine dissolved organic carbon. Limnol Oceanogr 42:1364-1374

Taylor GT, Iturriaga R, Sullivan CW (1985) Interactions of bactivorous grazers and heterotrophic bacteria with dissolved organic matter. Mar Ecol Prog Ser 23:129-141

Teira E, Pazó MJ, Serret P, Fernández E (2001) Dissolved or- 
ganic carbon (DOC) production by microbial populations in the Atlantic Ocean. Limnol Oceanogr 46:1370-1377

Unanue M, Azúa I, Arrieta JM, Labirua-Iturburu A, Egea L, Iriberri J (1998) Bacterial colonization and ectoenzymatic activity in phytoplankton-derived model particles: cleavage of peptides and uptake of amino acids. Microb Ecol 35:136-146

Urban-Rich J (1999) Release of dissolved organic carbon from copepod fecal pellets in the Greenland Sea. J Exp Mar Biol Ecol 232:107-124

Verity PG (1985) Grazing, respiration, excretion, and growth rates of tintinnids. Limnol Oceanogr 30:1268-1282

Verity PG, Stoecker DK, Sieracki ME, Nelson JR (1993) Grazing, growth and mortality of microzooplankton during the 1989 North Atlantic spring bloom at $47^{\circ} \mathrm{N}, 18^{\circ} \mathrm{W}$. DeepSea Res I 40:1793-1814

Vidal J (1980) Physioecology of zooplankton. IV. Effects of

Editorial responsibility: Karin Lochte,

Rostock, Germany phytoplankton concentration, temperature, and body size on the net production efficiency of Calanus pacificus. Mar Biol 56:203-211

Welschmeyer NA, Strom S, Goericke R, DiTullio G, Belvin M, Petersen W (1993) Primary production in the subarctic Pacific Ocean: Project SUPER. Prog Oceanogr 32:101-135

Wheeler PA, Kokkinakis SA (1990) Ammonium recycling limits nitrate use in the oceanic subarctic Pacific. Limnol Oceanogr 35:1267-1278

Wilhelm SW, Suttle CA (1999) Viruses and nutrient cycles in the sea. BioScience 49:781-788

Williams PJleB (1998) The balance of plankton respiration and photosynthesis in the open oceans. Nature 394:55-57

Williams PJleB (2000) Heterotrophic bacteria and the dynamics of dissolved organic material. In: Kirchman DL (ed) Microbial ecology of the oceans. Wiley-Liss, New York, p 153-200

Submitted: September 15, 2000; Accepted: August 13, 2001 Proofs received from author(s): October 18, 2001 